\title{
Myten om det galna geniet
}

\author{
Om neurosyflis i litteraturen och konsten
}

ATt KAlla SPECIELlt BEGÅVADE konstnärer genier har en lång tradition. Genikulten var särskilt omfattande på I80o-talet då författare, bildkonstnärer och kompositörer med fördel kategoriserades som osedvanligt begåvade och högrestående i sitt konstnärskap. De geniala konstnärerna, som i de flesta fall var män, skulle representera något extraordinärt och de ansågs ha osedvanliga förmågor att skapa något nytt och fantastiskt. Och ibland kunde deras speciella begåvning uppfattas gränsa till det mentalt instabila. Man ville se ett samband mellan galenskap och kreativitet.

Det finns en mängd psykologisk forskning i geniernas beskaffenhet från de första decennierna av I900-talet, när psykologin som ny vetenskap blommade upp i en rad olika riktningar. En av de tongivande forskarna i det här sammanhanget var den tyska psykiatern Ernst Kretschmer som i boken Geniala människor hävdar att människan, eller snarare mannen, föds till geni, och att genialiteten är en kombination av osedvanlig begåvning och speciella själsliga element som ibland kan stå sinnessjukdom nära. ${ }^{1}$ Det galna geniet kan ta form i en konstnär som i konstens namn hänsynslöst utnyttjar allt och alla omkring sig. I populärkulturen är personen inte sällan komisk, som "the nutty professor" eller "the mad scientist", oberäknelig, excentrisk och okonventionell. Den här artikeln fokuserar dock på en annan form av galenskap, den enda som kan härledas till en mikrob, nämligen

Den här artikeln baserar sig på en kommande bok som utförligare behandlar syfilis i konst, litteratur och opera.

I. Ernst Kretschmer, Geniala människor, Stockholm: Natur \& Kultur 1930, s. I4, 20, 59. Boken på tyska: Ernst Kretschmer, Geniale Menschen. Mit einer Porträtsammlung, Berlin, Heidelberg: Springer-Verlag 1929, https://doi.org/Io.1007/978-3-662-25738-8. 
neurosyfilis, som orsakas av bakterien Treponema pallidum, i äldre texter även kallad Spirochaeta pallida. ${ }^{2}$

Syfilis hör till de sjukdomar som fascinerat såväl författare som medicin- och idéhistoriker genom tiderna. Det har att göra med att den uppfattas som en social sjukdom, på samma sätt som alkoholism, tuberkulos och mentala problem. Dessa sjukdomar har en betydande inverkan på människors liv, relationer, familj, kultur, moral, litteratur och konst. ${ }^{3}$ Också det faktum att syfilis var svår att dölja, med karakteristiska eksem i ansiktet och på händerna, gjorde den skrämmande och mytomspunnen. ${ }^{4}$ Men det var inte bara de synliga eksemen som skrämde utan också vetskapen om att man kunde bli galen och utsättas för en plågsam och utdragen död. Susan Sontag har lyft fram att myterna kring syfilis var snarlika dem som skapades kring aids på I980-talet. Det har givetvis att göra med att båda sjukdomarna associeras med promiskuitet, men också med att de var obotliga och inverkade gravt på den smittades liv, inte sällan ledde de till döden. När det gällde aids ledde sjukdomen alltid till döden innan det fanns verksamma mediciner. ${ }^{5}$ Myterna har givetvis förändrats över tid. I dag finns det fortfarande många som minns när aids var en obotlig och skrämmande, dödlig sjukdom medan kunskaperna om syfilis är begränsade eftersom sjukdomen inte längre uppfattas som ett hot.

Redan historien om hur syfilis kom till Europa är en roman i sig. Den dominerande teorin är att den landsteg med Columbus besättning efter de vådliga resorna till Nya världen i slutet av I40o-talet. Besättningen förde med sig mässling och smittkoppor från Europa, som skördade miljoner människoliv på den amerikanska kontinenten, och i retur fick man syfilis med sig hem. Från mitten av I490-talet finns det uppteckningar om en hemsk sjukdom i Neapel, som härjade och snabbt spred sig över resten av Europa. ${ }^{6}$ Redan då visste man att sjukdomen smittade genom sexuell kontakt. Också mycket tidigt finns det samband mellan syfilis och litteratur; sjukdomen fick nämligen sitt

\footnotetext{
2. Johan Cullberg, En diktares kompost, Stockholm: Natur \& Kultur 20I2, s. I88-I89.

3. Claude Quétel, History of Syphilis, Cambridge: Polity Press I990, s. 2.

4. Susan Sontag, Illness as Metaphor and AIDS and its Metaphors, New York: Picador I990, S. I28-I29.

5. Ibid., s. IO4, II4.

6. Quétel, History of Syphilis, s. 34-44.
} 
namn genom ett poem från 1530 av den italienske läkaren, filosofen och vetenskapsmannen Girolamo Fracastoro, "Syfilis eller franska sjukan" ("Syphilis sive morbus gallicus"). ${ }^{7}$ Syfilis har nämnts vid olika namn under olika tider beroende på var man befinner sig. Utanför Frankrike kallades den franska sjukan, eller fransosen, medan den i Frankrike benämndes neapolitanska sjukan. ${ }^{8}$ Ibland har man talat om kopporna och i några fall har den inte alls nämnts eftersom den varit underförstådd; allmänheten har vetat att det handlar om syfilis, som i Henrik Ibsens pjäs Gengångare (Gengangere, I88I). ${ }^{9}$ Att nämna ordet har förmodligen uppfattats som skandalöst och i stället har författare omskrivit det. Gerda von Mickwitz novell "Messling” från I886 lyfter fram att man inte ens berättade för gifta kvinnor som smittats av sina män att de led av syfilis utan kallade det mässling. Läkare tyckte att det var onödigt att skrämma upp kvinnorna, och i stället skyddade man dem från vetskapen om dels att de led av en dödlig sjukdom, dels att deras män förmodligen varit otrogna. ${ }^{10}$

\section{SJUKDOMENS FYSISKA OCH PSYKISKA IMPLIKATIONER}

Syfilis indelas kliniskt i tre stadier. Det första infaller tre veckor efter smittan och tar sig uttryck i kraterliknande sår på det ställe på slemhinnan där infektionen startat, i regel på könsorganen. Utslagen kliar inte och kan vara små, vilket leder till att man i vissa fall inte upptäcker att man är smittad. Det andra stadiet, som infaller omkring tre månader efter det första, kännetecknas av utslag över hela kroppen, liknande mässling eller smittkoppor. Man har också feber, ont i lederna, värk i kroppen, magproblem och andra diffusa symptom. Också större

7. Ibid., s. $5^{2-53}$.

8. Ibid., s. Io.

9. Hilde Bondevik \& Knut Stene-Johansen, Sykdom som litteratur. I3 utvalgte diagnoser, Oslo: Unipub 20II, s. II7.

ı. Se Arne Toftegaard Pedersen, "Text och tabu på r88o-talet - om Gerda von Mickwitz 'Messling' och Ett giftermål, Joutsen / Svanen. Arsbok for forskning i finländsk litteratur 20I5, s. 62-8I, https://blogs.helsinki.fi/litteraturbanken/joutsensvanen/joutsen-svanen-2015/ (hämtad 29/II 2018) och Birgitta Ney,"Förord", Amanda Kerfstedt m.fl., Synd. Noveller av det moderna genombrottets kvinnor, Stockholm: Ordfronts förlag I993, s. 7-I9, https://litteraturbanken.se/forfattare/KerfstedtA/ titlar/Synd/sida/3/etext (hämtad 29/II 20I8). 
utslag i munnen kan förekomma. Efter det kan sjukdomen ligga latent i flera år eller ta sig uttryck i en rad allmänna symptom som lätt förväxlas med andra sjukdomar. Det tredje stadiet, eller tertiärstadiet, kan inträffa så sent som trettio år efter smittan och för med sig svåra symptom som hjärtfel, svår ledvärk och problem med koordinationen, blindhet, svåra magproblem, sönderfall av mjukdelar och stora krateraktiga sår och i vissa fall svåra neurologiska problem, så kallad neurosyfilis. Syfilis drabbar hela kroppen och den akuta dödsorsaken är ofta att ett blodkärl spricker (aneurysm) eller hjärtfel eller i vissa fall undernäring, eftersom syfilitikern ofta inte kan äta normalt. ${ }^{11}$ Sjukdomen var svår att diagnostisera innan det fanns säkra kliniska tester och det ledde till att den lätt spreds. I ett tidigt stadium kunde den förväxlas med andra veneriska sjukdomar som gonorré. Svårigheten att diagnostisera har också att göra med att sjukdomen har en mängd olika symptom som också förekommer i samband med andra sjukdomar, och som dessutom drabbar olika delar av kroppen i olika stadier. Fram till penicillinets genombrott efter andra världskriget, fanns inget effektivt botemedel mot syfilis. I äldre tider behandlade man sjukdomen med kvicksilver och senare med arsenikpreparat, som visserligen lindrade symptomen men som också kunde medföra nya problem, som svår salivutsöndring, tandlossning, förgiftningssymptom och i värsta fall döden. ${ }^{12}$

Sjukdomen har också förändrats över tid och muterat. Det var först i slutet av r7oo-talet som sjukdomen började angripa det centrala nervsystemet vilket ledde till neurosyfilis. Man utgår från att det var Napoleons arméer som snabbt spred denna form av sjukdom över hela Europa. ${ }^{13}$ Syfilis inverkade också olika på olika personer. Det finns uppgifter om att bara en tredjedel av de smittade drabbades av tertiärstadiet, men hur det egentligen förhåller sig finns det olika uppgifter om. Men säkert är att alla inte drabbades av neurosyfilis, i vissa fall därför att den drabbade dog i någon form av hjärt- eller kärlproblem innan de neurologiska problemen hann uppstå.

II. Deborah Hayden, Pox. Genius, Madness, and the Mysteries of Syphilis, New York: Basic Books 2003, s. 53-59.

I2. Petteri Pietikäinen, Hulluuden historia, Helsinki: Gaudeamus 2014, s. I22. För utförligare information, se Quétel, History of Syphilis.

I3. Pietikäinen, Hulluuden historia, s. I20-I2I. 
Neurosyfilis, eller den form av syfilis som angriper hjärnan, kallas också dementia paralytica, pares eller paralys. Den franske psykiatern Antoine-Laurent Bayle var den första som identifierade neurosyfilis som en särskild sjukdom i början av I820-talet, även om han då ännu inte visste att det handlade om en form av syfilis; att det förhöll sig så kunde man konstatera först på I870-talet. Neurosyfilis kunde föra med sig en rad olika symptom i olika stadier av sjukdomens utveckling, från en känsla av överentusiasm och megalomani till depression, paranoia och psykos, för att sedan övergå i demens. I slutskedet kunde personen uppleva ett stadium av eufori och manisk kreativitet. Symptomen kunde vara snarlika sådana som förekommer i samband med bipolärt syndrom. Neurosyfilis kan också leda till tabes dorsalis, vilket innebär en degenerering av nerver i ryggmärgen. Det för med sig problem med kroppsrörelser, magproblem, hörsel- och synnedsättning. ${ }^{14}$

\section{Syfilis som idé}

Vid en första anblick kan man tänka sig att syfilis var något som drabbade speciellt många manliga konstnärer. Med säkerhet vet man att Gustave Flaubert, Franz Schubert, Robert Schumann, E.T.A. Hoffmann, Charles Baudelaire, Heinrich Heine, Vincent van Gogh och James Joyce led av syfilis. ${ }^{15}$ I Finland har konsthistorikern Marja Lahelma påvisat att Hugo Simberg dog till följd av syfilis. ${ }^{16}$ Bland kvinnliga författare är det bara Karen Blixen som nämns i syfilissammanhang. På senare tider har man också i filmform lyft upp den ökända amerikanska sångerskan Florence Foster Jenkins, som smittades av sin äkta man på bröllopsnatten och som senare dog till följd av syfilis. Orsaken till att det finns så många kända manliga syfilitiker är förmodligen att deras liv dokumenterats så noggrant, inte sällan som en följd av genikulten kring dem. Till en början har biografer försökt dölja eller ignorera att den beundrade konstnären lidit av syfilis eftersom det förde med sig ett stigma. I vissa fall har det också handlat om att man som biografisk forskare missat sjukdomen eller

I4. Ibid., s. $5^{6-58 .}$

15. Hayden, Pox.

I6. Marja Lahelma, Hugo Simberg, Helsingfors: Ateneum 20I7, s. 27, 64. 
tyckt att den är irrelevant. ${ }^{17}$ Så sent som 2013 avslöjade musikern och musikforskaren Paul Kildea att den brittiske kompositören Benjamin Britten i själva verket dog i syfilis I976, en skandal som väckte debatt i The Guardian. ${ }^{18}$ Fortfarande uppfattas sjukdomen som skamlig. Förmodligen har även okunskapen om vidden av sjukdomens inverkan på människokroppen och den drabbades psykiska liv varit en orsak till att man låtit bli att nämna den i den biografiska berättelsen. Jag tror också att det känts moraliskt diskutabelt att behandla en så pinsam sjukdom i en biografi; den indikerar ju ändå promiskuitet, frågor om skam, skuld, sexualitet och otrohet, och dessutom är den skrämmande och oberäknelig. Däremot har man gärna behandlat konstnärers tuberkulossjukdom i tidiga biografier, detta för att tuberkulos uppfattats som en förandligad sjukdom, som dessutom drabbar andningsorganen och som smittar oförskyllt genom luften. Man har velat se ett samband mellan tuberkulos och poetiska skönsjälar, och menat att det är speciellt känsliga personer som drabbas. Och man har gärna estetiserat tuberkulosdöden, speciellt när det gäller kvinnor, och frossat i hur exempelvis den undersköna Kameliadamen tynar bort på sin divan. På sätt och vis har man tyckt att tuberkulos är en poetisk sjukdom, där den drabbade blek och tärd tynar bort. Goda exempel på detta är John Keats, Franz Kafka och givetvis Edith Södergran.

Att manliga författare, bildkonstnärer och kompositörer särskilt ofta led av syfilis beror inte på att de skulle ha varit särskilt utsatta jämfört med andra yrkeskategorier eller med kvinnor, men de levde ofta ett oregelbundet liv och uppsökte prostituerade, vilka inte sällan var källan till smittan. Också andra män från olika samhällsklasser frekventerade bordeller och gatuprostituerade, smittades och bar hem smittan till den äktenskapliga sängen. Länge var det sexualmoraliskt accepterat att unga män och även gifta män besökte bordeller och levde ut sin sexualitet där. Och om man blev smittad kunde det dröja flera år innan man insåg att så var fallet. Dessutom smittar sjukdomen

17. Hayden, Pox, s. 61, 64-65, 318.

I8. Paul Kildea, Benjamin Britten. A Life in the Twentieth Century, London: Allen Lane 2013. Om debatten se t.ex. Charlotte Higgins,"Benjamin Britten Syphilis'extremely unlikely', says cardiologist", The Guardian 22/I 2013, https://www.theguardian. $\mathrm{com} / \mathrm{music} / 20 \mathrm{I}_{3} / \mathrm{jan} / 22 /$ benjamin-britten-syphilis-condition-unlikely-cardiologist (hämtad 29/II 20I8). 
under de tre första åren, vilket ledde till att det var svårt att begränsa spridningen. Syfilis var så till vida en demokratisk sjukdom att den drabbade fattig som rik, piga som kung, likvärdigt. Allt handlar om att syfilis var mycket vanligt på I80o-talet och ända fram till andra världskriget då penicillinet började användas som ett effektivt botemedel. Syfilis finns fortfarande i dag, men kan stoppas med antibiotika innan allvarligare symptom utvecklas.

Det är mycket svårt att veta något om utbredningen av könssjukdomar i slutet av I80o-talet. Ett av de få undantagen är armén där man hade regelbundna hälsogranskningar som dokumenterats. På I87o-8o-talet fanns det avgjort mest syfilis i England, sedan kom militären i Paris och Wien och efter det Finland. ${ }^{19}$ En orsak till att syfilis var så vanlig i Finland var att landet upplevde flera krig där folk, framför allt militärer, rörde sig över stora områden. ${ }^{20}$ Men man kan också tänka sig att det stora antalet handelsresande och sjömän starkt bidrog till den här trenden. Syfilistoppen i Finland inföll på I86o-talet då landets ekonomi var som mest ansträngd till följd av missväxt, hungersnöd och epidemier. Enligt medicinalstyrelsen fanns det under den här tiden fler syfilisfall i Finland än i något annat land i Europa. ${ }^{21}$ Det handlade förstås om att stora mängder människor rörde sig längs vägarna på jakt efter bröd och värme, men också om att hygienen var dålig. Syfilis kunde nämligen också smitta via smutsiga sängkläder eller handdukar.

De prostituerades situation var sällan något som lyftes fram, i annat fall än då de fick bära skulden till smittan. Men någon hade förstås också smittat dem i något skede. I slutet av I8oo-talet och början av I90o-talet försökte man hålla syfilisspridningen under kontroll genom att reglera prostitutionen och tvinga de prostituerade att genomgå regelbundna hälsokontroller och till och med spärra in dem på speciella syfilisanstalter. ${ }^{22}$ I själva verket var det män i rörliga yrken som

19. Oiva Turpeinen, Kuppa. Kuninkaan ja kerjäläisen vitsaus, Somero: Amanita 20I2, s. 92 .

20. Ibid., s. I23.

2I. Ibid., s. Io.

22. Kira Gronow,"Prostituoituja oli Helsingissä sata vuotta sitten niin paljon, että heitä varten perustettiin pakkohoitola - Kaupunkilaisten karttamassa 'Kuppalassa' toteltiin ankaraa kuria, tapeltiin ja opetettiin ammatin saloja", Helsingin Sanomat I2/II 20I7, https://www.hs.fi/kulttuuri/art-2000005445673.html (hämtad 29/rI 20I8). Se 
effektivast spred smittan över större områden, sådana som militärer, handelsmän och sjömän. Och prostituerade följde ofta i arméernas spår och rörde sig frekvent i hamnarna. Kvinnornas berättelser blev ofta oskrivna, framför allt de prostituerades, men också de gifta kvinnornas. I min forskning har jag hittat bara ett biografiskt exempel på en gift kvinna med begynnande neurosyfilis och det är Mary Todd, hustru till Abraham Lincoln. Hon hade smittats av sin make. Mot slutet av sitt liv betedde hon sig bisarrt och blev fast för snatteri, men man har inte kunnat påvisa att hon skulle ha blivit galen, det var bara hennes beteende som förändrades. ${ }^{23}$

\section{DEN GALNE KONSTNÄREN}

Till de mest kända personerna som drabbades av neurosyfilis hör författaren Guy de Maupassant (1850-I893). Han skröt gärna över sina sexuella erövringar, att han en gång hade haft samlag med sex prostituerade på en timme. ${ }^{24}$ Flera av hans noveller handlar om prostituerade och bordelliv. När han var i tjugoårsåldern blev han själv smittad av syfilis av en prostituerad men fick sin diagnos först sex, sju år senare. I mars 1877 skrev han till sin vän Robert Pinchon:"Halleluja, jag har kopporna, så nu behöver jag inte vara orolig att bli smittad längre, och jag knullar gathororna och slamporna, och efteråt berättar jag för dem 'jag har kopporna.' De är rädda och jag bara skrattar." 25 I novellen "Säng 29"/ "Säng nummer 29"26 ("Le Lit 29", I884) har den vackra fransyskan Irma smittats av syfilis av en preussare och efter det gjort sitt bästa att smitta så många andra preussare som möjligt i sin privata krigföring under det fransk-preussiska kriget. År I88o blev

även Kirsi Vainio-Korhonen, Musta-Maija ja Kirppu-Liisa. Seksityöläiset I8oo-luvun alun Suomessa, Helsinki: Suomalaisen Kirjallisuuden Seura 2018.

23. Hayden, Pox, s. I25-I26.

24. Ibid., s. I42.

25. "Alleluia j'ai la vérole, par conséquent je n'ai plus peur de l'attraper et je baise les putains des rues, les rouleuses des bornes et après les avoir baisées je leur dis: 'J'ai la vérole.'Et elles ont peur et moi je ris.", Claude Quétel, Le mal de Naples. Historie de la syphilis, Paris: Seghers 1986, s. I63. Översatt från engelska av AR ur Quétel, History of Syphilis, s. I29.

26. I t.ex. Guy de Maupassant, Fettpärlan och andra noveller, översättning av Jakob Gunnarsson, Uddevalla: Niloé r99o. 
Maupassant nästan blind på ena ögat, ett av de tidiga symptomen på neurosyfilis, vid sidan av hörselproblem och svår huvudvärk. ${ }^{27}$ Det här sammanföll med Maupassants genombrott, novellen "Fettpärlan" ("Boule de suif", I880), som även den handlar om en prostituerad kvinna på resa från Rouen till Le Havre på flykt undan kriget, tillsammans med två nunnor, ett fabrikörspar, en handelsman och hans hustru och en greve och en grevinna. ${ }^{28}$

Som jag nämnde tidigare har det funnits olika sätt att som biograf förhålla sig till sin protagonists syfilis. Maupassants förste biograf, Robert Sherard, hör till dem som på ett anmärkningsvärt sätt framhåller teorin om att det inte är en tillfällighet att Maupassants genombrott sammanföll med diagnosen för neurosyfilis, eftersom sjukdomen enligt honom kunde stimulera hjärncellerna till extraordinär aktivitet och förhöja en genial hjärna till ännu genialare skapelser. ${ }^{29}$ Mellan åren I880 och I89I var Maupassant oerhört produktiv och gav ut en eller flera böcker nästan varje år. Om det handlade om en för honom normal arbetstakt, eller om det berodde på rädslan för att dö för tidigt, eller om det var en följd av hans neurosyfilis, är omöjligt att veta. Novellen "Horla"30 ("Le Horla"), som utkom I887, har tolkats som en förstudie till den sinnessjukdom som Maupassant sedan drabbades av några år senare. Det är en berättelse om en inre resa, fylld av panisk förföljelsemani och ångest. År I89I pinades Maupassant av en fruktansvärd huvudvärk, sömnlöshet och depression alternerade av eufori. Följande år drabbades han av hallucinationer och påstod att han blivit adlad till greve. Han försökte också skära halsen av sig och skjuta sig. I januari I893 blev han inspärrad på mentalsjukhus i Paris. Ibland kunde han vara förhållandevis normal för att däremellan hallucinera och bete sig våldsamt. Han fantiserade att han var en rik yngre bror till Jesus Kristus, slickade väggarna i sin cell och sparade

27. Hayden, Pox, s. I47.

28. Guy de Maupassant, Fettpärlan, översättning av Marie Berthelius, Lund: Bakhåll 2019.

29. Robert Sherard, The Life, Work and Evil Fate of Guy de Maupassant, New York: Brentano's 1926, s. I89.

30. Novellen finns översatt till svenska i en rad antologier men också i Guy de Maupassant, Horla, översättning av Sam J. Lundwall, Bromma: Lundwall Fakta \& fantasi 1993. 
sin urin eftersom han trodde den var gjord av diamanter. ${ }^{31}$ Ibland ylade han som en hund och planterade pinnar i marken för att driva upp nya baby-Maupassanter. ${ }^{32}$

Syfilis förekommer i alla konstarter, inte bara i litteraturen. Som ett parallellfall till Maupassants frenetiska produktion innan han blev själsligt oförmögen att skriva, finns den italienske kompositören Gaetano Donizetti (I797-I848). Han komponerade inte mindre än sjuttio operor, bland dem hans mest berömda opera Lucia di Lammermoor, under en period på trettio år. Utöver dessa skrev han också ett tjugotal orkesterverk och symfonier, mer än I5o sakrala verk, fyrtio kammarstycken, femtio pianostycken och nästan trehundra sånger. Tillsammans blir det omkring 660 olika musikaliska kompositioner. ${ }^{33}$ Precis som i fallet Maupassant, är det omöjligt att säga om Donizetti hade varit lika produktiv om han inte hade varit sjuk. Men även om han var förmögen att skapa en så stor mängd musik av hög kvalitet trots sin sjukdom, kom den att ha en förödande inverkan på hans personliga liv. Förmodligen infekterade han sin hustru och deras tre barn dog strax efter födseln, möjligen som en konsekvens av syfilissmitta. Också hustrun dog i samband med den sista förlossningen. ${ }^{34}$ Donizetti led av svår huvudvärk, konvulsioner, hallucinationer och feberattacker. Han betedde sig också irrationellt och obscent och gjorde sig skyldig till kriminella handlingar. År I845 intogs han på ett mentalsjukhus i Paris och blev till slut paralyserad, psykotisk och tappade helt förmågan att kommunicera. ${ }^{35}$

\section{Doktor Faustus}

Robert Sherard hörde alltså till de biografer som på i920-talet spred myten om att neurosyfilis kunde leda till en euforisk skaparkraft

31. Hayden, Pox, s. I49-I50.

32. Sarah Dunant, "A pain in the arts: How syphilis affected creativity", Mail $\mathbb{E}^{\circ}$ Guardian 3I/5 20I3, https://mg.co.za/article/2013-05-3I-pain-in-the-arts-a-poxon-genius (hämtad 29/II 2018).

33. Eddie Persson, Drabbad av Venus. Gaetano Donizetti - ett geni i sönderfall, Stockholm: Santérus förlag 2009, s. II.

34. Tomasz F. Mroczkowski, History, Sex and Syphilis. Famous Syphilitics and Their Private Lives, Bradenton: BookLocker 2015, s. I34.

35. Ibid., s. I36-I37. 
och osedvanlig genialitet. Thomas Mann leker med den här tanken i romanen Doktor Faustus (1947). Mann hör till de författare som i flera av sina centrala verk intresserade sig för sjukdom som tema. I novellen "Döden i Venedig"36 ("Der Tod in Venedig", I9I2) stapplar den febrige författaren Gustav von Aschenbach omkring i en badort utanför Venedig som drabbats av kolera. Romanen Bergtagen ${ }^{37}$ (Der Zauberberg, 1924) handlar om Hans Castorp som besöker en vän på ett schweiziskt lungsanatorium, för att till slut själv drabbas av tuberkulos. I Doktor Faustus är syfilis ett centralt tema, eller snarare myten om den, uppfattningen om att syfilis i sitt tertiärstadium kan leda till kreativ genialitet.

Romanen är en av de mest berömda fiktiva biografierna och anges vara skriven av den fiktive filosofie doktorn Sereneus Zeitblom, som hyser en hejdlös beundran för barndomsvännen och komponisten Adrian Leverkühn, en avhoppad teologistuderande som satsar hela sitt liv på en musikalisk karriär. Leverkühn har flera likheter med den hyllade komponisten Arnold Schönberg ${ }^{38}$ och inte minst med filosofen Friedrich Nietzsche, ${ }^{39}$ som också hör till historiens berömda syfilitiker och som dessutom blev galen till följd av sjukdomen. Leverkühn låter medvetet en prostituerad smitta honom med syfilis ${ }^{40}$ och gör på så sätt en pakt med djävulen, likt Faust-gestalten som säljer sin själ för att få makt och framgång. Leverkühn smittas av en sjukdom som fråntar honom möjligheten till kärlek och utlovas i stället tjugofyra aktiva år då han kan åstadkomma de mest fantastiska musikaliska verk och bli den största kompositören i det samtida Tyskland. Det är oklart om

36. Thomas Mann, Döden i Venedig. Tonio Kröger, översättning av Karl Vennberg och Walborg Hedberg, Stockholm: Bonnier 20Ir.

37. Thomas Mann, Bergtagen, översättning av Ulrika Wallenström, Stockholm: Bonnier 2OII.

38. Schönberg, som hjälpte Mann med musikalisk sakkunskap för romanen, blev själv mycket indignerad över att associeras med syfilis och galenskap på detta sätt och tog offentligt avstånd från det i en insändare 1949, John F. Fetzer, Changing Perceptions of Thomas Mann's Doctor Faustus: Criticism 1947-1992, Columbia, SC: Camden House 1996, s. I5.

39. Det finns en stor mängd studier kring de biografiska likheterna mellan Nietzsche och Leverkühn, Fetzer. Changing Perceptions of Thomas Mann's Doctor Faustus, s. 42.

40. Thomas Mann, Doktor Faustus. Den tyske tonsättaren Adrian Leverkühns liv berättat av en vän, översättning av Ulrika Wallenström, Stockholm: Albert Bonniers förlag 2015 , s. 215-216. 
mötet med djävulen ska uppfattas som verkligt eller om det handlar om en hallucination som Leverkühn sedan tecknar ned i form av en dramatiserad dialog och ger till sin vän, Zeitblom. ${ }^{41}$ Berättelsen är mångbottnad; i samband med att protagonisten sluter sin pakt försvinner hans läkare under mystiska omständigheter. ${ }^{42}$ Detta för att sjukdomen fritt ska ta över och sprida sig till hjärnan. Djävulen hävdar övertygande

att skapande sjukdom, sjukdom som skänker snille, sjukdom som högt till häst tar hindren, i djärvt rus spränger fram från klippa till klippa, är tusen gånger kärare för livet än hälsan som hasar fram till fots. ${ }^{43}$

I ett framskridet stadium av Leverkühns sjukdom liknas hans fysiska smärtor vid den lilla sjöjungfruns i H.C. Andersens sagoäventyr. När hon får ben att gå med känner hon skärande smärtor likt knivstick. Hon tror sig fă en odödlig själ, lik människans, genom att byta sin fiskstjärt mot människoben och på så vis vinna prinsens kärlek. ${ }^{44}$ Fiskstjärten kan ses som en parallell till Leverkühns frihet och förmåga att älska som han byter bort mot något han tror är mer värdefullt, musikalisk genialitet. Mot slutet kommer känslan av makt och härlighet att dominera över Leverkühns smärtor som stegras till något gudomligt. ${ }^{45}$ Men priset för att uppnå detta är således att Leverkühn inte tillåts älska. Djävulen säger: "Kärlek är förbjudet för dig, i den mån den värmer. Ditt liv ska vara kallt - därför får du inte älska någon människa.” Den bländande extasen ska tas från själen och känslolivet. ${ }^{46}$

Genom att medvetet låta sig smittas lever Leverkühn i fortsättningen i celibat; sjukdomen gör honom sexuellt återhållsam. I stället

4I. Ibid., s. 30I-337.

42. Ibid., s. 219-220, 317.

43. Ibid., s. 328, "Genie spendende Krankheit, Krankheit, die hoch zu Ross die Hindernisse nimmt, in kühnem Rausch von Fels zu Felsen sprengt, tausendmal dem Leben lieber ist als die zu Fusse latschende Gesundheit.”, Thomas Mann, Doktor Faustus. Das Leben des deutschen Tonsetzers Adrian Leverkühn erzäblt von einem Freunde, Frankfurt am Main: S. Fischer Verlag I986, s. 323.

44. Mann, Doktor Faustus, s. 313, 456. För Andersens text, se H.C. Andersen, H.C. Andersens Eventyr, band I, Köpenhamn: C.A. Reitzel ı99o, s. 87-Io6.

45. Mann, Doktor Faustus, s. 328.

46. Ibid., s. 336. "Liebe ist dir verboten, insofern sie wärmt. Dein Leben soll kalt sein - darum darfst du keinen Menschen lieben.", Mann, Doktor Faustus, I986, s. 332. 
för att tänka på ett erotiskt liv fokuserar han helt och fullt på sitt eget skapande. Det här kan ses som en parallell till Manns eget förhållningssätt till sin outlevda homosexualitet som framgår i bevarade dagböcker. ${ }^{47}$ Men även om Leverkühn lever för musiken, längtar han också efter kärlek och försöker sig på olika relationer till en rad kvinnor. Men alla personer som han älskar tas ifrån honom på ett eller annat sätt och på så vis fullbordas den faustiska pakten. De känslor han hyser för andra människor avvisas på de mest brutala sätt, samtidigt som de nära människorelationer han lyckas upprätthålla är avmätta. Det korrelerar med känslovärlden i hans konstnärskap, som visserligen är ett genialt pionjärarbete men som samtidigt också är intellektuellt och kyligt. Och i sin musik rör han sig allegoriskt nära undergången. Den sista och mest geniala kompositionen heter"Apokalipsis cum figuris", och är en hyllning till Albrecht Dürers träsnitt som illustrerar den sista boken i Nya testamentet. Apokalyps betyder ursprungligen uppenbarelse men associeras i allmänhet med jordens och mänsklighetens undergång. Zeitblom ser en klar koppling mellan kör- och orkesterverket och Leverkühns skaparkraft som toppas av frenetisk eufori men som hotas av total kollaps och förödelse likt Dantes "Inferno". ${ }^{48}$ Också bokens motto är ett citat ur "Inferno" där skalden stiger ned i underjorden. Rent fysiskt börjar Leverkühn mot slutet av sitt liv likna Ecce homo i Zeitbloms ögon. Kompositörens pipskäggsbeklädda haka lutar alltmer mot axeln, vilket påminner om hur Jesus avbildas på korset, med halvöppen mun och uttryckslösa ögon. ${ }^{49}$ Genialiteten har sitt pris i kroppens ohjälpliga sönderfall. Redan i början av romanen reflekterar Zeitblom över det besvärliga begreppet genial; han vill kalla sin vän en genial musiker men är medveten om att det inte bara implicerar en begåvning som når högre sfärer utan också handlar om något demoniskt och förnuftsvidrigt. ${ }^{50}$

47. Fetzer, Changing Perceptions of Thomas Mann's Doctor Faustus, s. 46, II6. Se även Michael Wood,"Impossible Wishes", London Review of Books, vol. 25, nr 3, 6/2 2003, s. 3-6, https://www.lrb.co.uk/v25/no3/michael-wood/impossible-wishes (hämtad 29/II 20I8).

48. Mann, Doktor Faustus, s. 474-478. "Inferno" ingår i Dante Alighieri, Den gudomliga komedin, översatt och kommenterad av Ingvar Björkeson, inledning av Olof Lagercrantz, Stockholm: Natur och kultur 2006.

49. Mann, Doktor Faustus, s. 496, 523.

50. Ibid., s. 22-23. 
Sjukdomen får således en katastrofal inverkan på komponisten, som till slut blir sinnessjuk och försjunker i ett regredierat vegeterande tillstånd. Det har setts som en allegori för romanens idé om Europas förfall, den tyska kulturens paradoxala spänning, att den å ena sidan gett upphov till genial konst, å andra sidan utgjort politisk grogrund för nationalsocialismen. Det märkliga med romanen är att Mann aldrig nämner sjukdomen syfilis vid namn, även om han nämner bakterien som orsakar den. ${ }^{51}$ Inte heller nämner han Adolf Hitler vid namn utan refererar till honom som "den ohygglige mannen". ${ }^{52}$ Syfilis blir på sätt och vis ett annat namn för nazismen, sjukdomen angriper samtliga delar av Leverkühns kropp precis som nationalsocialismen angrep alla delar av det tyska samhället, för att till slut förgöra det.

Thomas Mann drabbades inte själv av syfilis, men han är ändå oerhört väl insatt i sjukdomens förlopp och lömska sidor. Den slovenske neurologen Urož Rot menar att Mann i själva verket mycket initierat beskriver en rad varianter av neurologiska sjukdomar i sin roman. ${ }^{53}$ Det är alltså inte bara neurosyfilis som beskrivs utan också bakteriell meningitis, som drabbar Leverkühns systerson Nepomuk, migrän och en rad neurologiska spasmer och darrningar. Forskare som Christiane Walter lyfter fram psykopatologin, vetenskapen om mentala sjukdomar, som en central infallsvinkel i studiet av Doktor Faustus och hävdar att det är fråga om en psykiatrisk roman. ${ }^{54}$

På bokens sista sidor drabbas kompositören Leverkühn av en sjukdomsattack $^{55}$ och lever efter det i tio år som en dement åldring, på ett barns mentala nivå. Först tas han in på en nervkuranstalt för att sedan föras hem och vårdas av sin mor de sista åren. I något skede gör han ett desperat försök att ta sitt liv genom att dränka sig, men hittas i sista stund. Det kan tolkas som ett försök att bli kvitt pakten med djävulen. Död för egen hand kunde kanske åtminstone rädda

5I. Ibid., s. 3I4.

52. Ibid., s. 633. "Der grausige Mann”, Mann, Doktor Faustus I986, s. 637.

53. Urož Rot,"Thomas Mann: Neurological Cases from Doctor Faustus”, Practical Neurology 2004:4, s. I8I. Se även François Boller \& Nicoletta Caputi, ”Thomas Mann's Depiction of Neurosyphilis and Other Diseases", Journal of the History of the Neurosciences, vol. 27, 2018:I, s. I-9, https://doi.org/I0.1080/o964704X.2017.I315288.

54. Christiane Walter, Zur Psychopatologie der Figuren in Thomas Manns Doktor Faustus', Frankfurt am Main: P. Lang I991.

55. Mann, Doktor Faustus, s. 66r. 
hans själ. ${ }^{56} \mathrm{Vid}$ ett sista besök hos Leverkühn, beskriver Zeitblom sin vän i sakrala bilder:

Längst in i rummet, på en schäslong vars fotända var vänd mot mig så att jag kunde se honom i ansiktet, låg under en lätt yllefilt han som en gång varit Adrian Leverkühn och vars odödliga del nu heter så. De bleka händerna, vilkas känsliga form jag alltid hade älskat, låg korsade på bröstet som på en medeltida gravfigur. Skägget som grånat ytterligare drog ut det avsmalnande ansiktet ännu mer på längden, så att det nu slående liknade det hos en ädling av E1 Greco. Vilken hånfull naturens nyck, skulle man vilja säga, att den kan alstra en bild av högsta förandligande där som anden har flytt sin kos! ${ }^{57}$

Thomas Mann ger inget svar på om det är neurosyfilis som gör Leverkühn genial. Eller om det handlar om vetskapen om att timglaset håller på att rinna ut, att livet är begränsat och fyllt av smärta, och att denna smärta och dödsångest kan kanaliseras i kreativitet, inte bara kvantitativ utan också kvalitativ. Det här påminner om en tanke som Edith Södergran på sin tid kastade fram, om att hon, när hon insjuknade i tuberkulos, drog den stora lotten. ${ }^{58}$ Hon kunde använda sin svåra sjukdom i ett kreativt syfte, närheten till döden gjorde henne mer känslig och förde henne närmare den poetiska konsten. Det finns myter om att tuberkulos kunde leda till febrig eufori och livsextas, och på samma sätt kunde syfilis leda till ett slags eufori som handlar om att man kom närmare en själslig upplevelse. Man kan uppleva sinnliga intryck starkare, se färger starkare, uppleva saker på ett extatiskt sätt. Åtminstone om man får tro Karen Blixen som menade att den syfilis

56. Ibid., s. 666-667.

57. Ibid., s. 669. "Im Hintergrunde des Zimmers, auf einer Chaiselongue, deren Fussende mir zugekehrt war, so dass ich ihm ins Gesicht sehen konnte, lag unter einer leichten Wolldecke der, der einst Adrian Leverkühn gewesen war, und dessen Unsterbliches nun so heisst. Die bleichen Hände, deren sensitive Bildung ich immer geliebt hatte, lagen, wie bei einer Grabfigur des Mittelalters, auf der Brust gekreuzt. Der stärker ergraute Bart zog das verschmälerte Gesicht noch mehr in die Länge, so dass es nun auffallend dem eines Greco'schen Edlen glich. Welch ein höhnisches Spiel der Natur, so möchte man sagen, dass sie das Bild höchster Vergeistigung erzeugen mag dort, wo der Geist entwichen ist!", Mann, Doktor Faustus 1986, s. 675 .

58. Agneta Rahikainen, Kampen om Edith. Biografi och myt om Edith Södergran, Helsingfors: Schildts \& Söderströms 2014, s. 337. 
hon smittades av i sin ungdom av sin äkta man, var det pris hon fick betala för sin konst. Också hon föreställde sig att hennes förmåga att berätta historier handlade om en pakt med djävulen. ${ }^{59}$

\section{DEN GALNE FILOSOFEN}

Redan när Doktor Faustus utkom såg man paralleller mellan Leverkühn och Friedrich Nietzsche. Också Nietzsche var en tidigare teologistuderande, komponerade musik och smittades av syfilis i unga år då det inte fanns någon effektiv medicinering.

I januari 1889 skrev Nietzsche en rad förvirrade vykort, bland annat till Vatikanen, undertecknade "den korsfäste". Hans gamle vän Franz Overbeck har vittnat om hur han deklamerande och sjungande fällde briljanta utsagor samtidigt som han hävdade att han är den som skall komma efter Gud som är död. Under denna forcerade monolog ackompanjerade han sig själv på piano. Kort efter denna episod blev han intagen på ett mentalsjukhus i Basel. ${ }^{60}$ Senare flyttades han till en psykiatrisk klinik i Jena. Där gestikulerade och grimaserade han vilt medan han talade och smetade omkring sin avföring och drack sin urin för att däremellan verka fullständigt normal. På kliniken behandlades han med kvicksilversalva. Senare blev han utskriven och sköttes de sista åren hemma av sin mor och syster. ${ }^{61}$ Den berömde neurologen och psykiatern P. J. Möbius ${ }^{62}$ publicerade 1902 Über das Pathologische bei Nietzsche, där han i detalj redogör för Nietzsches sjukdomsförlopp, och även försöker utreda i vilket sammanhang han blivit smittad. Det visade sig svårt eftersom det inte finns någon som helst dokumentation över att Nietzsche skulle ha haft en sexuell relation med någon över huvud taget. ${ }^{63}$ Elisabeth Förster-Nietzsche, den berömde filosofens syster som förvaltade, förvanskade och utgav hans verk, gjorde sitt

59. Judith Thurman, Karen Blixen. Ett diktarliv, Borås: Forum I986, s. I75.

6o. Hayden, Pox, s. I74-I76.

6r. Ibid., s. I77-I79.

62. Paul Julius Möbius är numera mest refererad till i feministisk forskning på grund av hans verk Über den physiologischen Schwachsinn des Weibes (I900) som fick en stor spridning, och som hävdade att kvinnan var både intellektuellt och moraliskt en lägrestående varelse. Karin Johannisson, Den mörka kontinenten, Stockholm: Norstedts I994, s. 45 .

63. Hayden, Pox, s. I8I. 
bästa att hemlighålla broderns sjukdom för allmänheten. Men eftersom Möbius redan offentliggjort den pinsamma sanningen anlitade hon en av broderns läkare, som kunde intyga att Nietzsche hade blivit smittad medan han arbetade som volontär fältsjukvårdare I870 och i en ambulans oförsiktigt rökt en cigarr som infekterats, något som är möjligt men inte särskilt sannolikt. ${ }^{64}$

Året innan Nietzsche blev mentalt sjuk, I888, var han oerhört produktiv och skrev Götzen-Dämmerung, oder, Wie man mit dem Hammer philosophiert, Der Antichrist, Ecce Homo och Nietzsche contra Wagner. Det har spekulerats mycket om han möjligen redan då var mentalt sjuk. Enligt Deborah Hayden har man inom syfilisforskningen kunnat påvisa att tiden innan galenskapen bryter ut hos de drabbade kan präglas av mystiska visioner, messianska profetior, känslor av grandiositet och extrem klarhet i kombination med ytterlig hämningslöshet. Vid julen I888 var Nietzsche övertygad om att han inom två månader skulle vara den mest kända personen i världen. Så övertygad var han om sin briljans. Under sin livstid lär han dock ha sålt bara några hundra exemplar av sina böcker, men ingen kan förringa den betydelse han haft på senare tiders västerländska litteratur och filosofi. Hans profetia blev således besannad, men det fick han aldrig själv uppleva. ${ }^{65}$

Också Thomas Mann har skrivit om Nietzsches exceptionella genialitet:"Hans öde var hans genialitet. Men det finns ett annat namn för denna genialitet: sjukdom." ${ }_{66}^{6}$ Mann har noggrant studerat Nietzsches sjukdomsförlopp eftersom det så väl dokumenterats av forskare som Möbius. Deborah Hayden lyfter fram en tydlig parallell mellan det sätt på vilket den berömde filosofen möjligen fick sin infektion och Leverkühns situation. ${ }^{67}$ Den oftast anförda berättelsen handlar om hur Nietzsche som student 1865 besökte en bordell i Köln men blev så förskräckt av åsynen av de vulgära kvinnorna att han genast tog sin tillflykt till pianot, som han fann vara det enda själfulla i sa-

64. Hayden, Pox, s. 182.

65. Ibid., s. I75-I76.

66. "Sein Schicksal war sein Genie. Aber dieses Genie hat noch einen anderen Namen. Er lautet: Krankheit". [Översättning till svenska AR], Thomas Mann,"Nietzsche's Philosophy in the Light of Recent History", Thomas Mann, Last Essays, New York: Alfred A. Knopf i959, s. I44.

67. Hayden, Pox, s. I85-I86. 
longen, och spelade några ackord, vilket genast befriade honom från känslan av förfäran. Han berättar historien i ett brev till sin vän Paul Deussen, som senare intygade att Nietzsche aldrig rörde vid en kvinna och således inte heller kunde ha blivit smittad av någon prostituerad. Ändå anses bordellbesöket i Köln vara orsaken till smittan, åtminstone i populära biografier. När den oskuldsfulle Adrian Leverkühn besöker sin bordell går han genast fram till pianot och spelar några ackord, men han drabbas inte av obehag, utan i stället kommer en av kvinnorna fram och smeker hans kind. ${ }^{68}$ I motsats till Nietzsche som blir äcklad, blir Leverkühn besatt av tanken att ett år senare uppsöka samma kvinna för att ligga med henne. Men hon varnar honom och berättar att hon lider av syfilis och Zeitblom beskriver vännens situation i känsloladdade ordalag:

Och milda himmel, var det inte kärlek också, eller vad var det, vilken galen lust, vilken vilja att fresta Gud och våga, vilken drift att inlemma straffet i synden, slutligen: vilket djupt hemligt begär efter demonisk befruktning, efter en dödligt frigörande chymisk förändring av hans natur verkade så att den varnade struntade $\mathrm{i}$ varningen och pockade på att äga detta kött? ${ }^{69}$

Också Nietzsche lär ha återvänt till samma bordell i Köln och möjligen då fått sin infektion, om det sedan var av en prostituerad eller genom närkontakt med bordellpianot må vara osagt. Det finns också teorier om att Nietzsche skulle ha blivit smittad genom en homosexuell relation. ${ }^{70}$ I den biografiska litteraturen beskrivs han antingen som asexuell, erotiskt misslyckad, sexuellt besatt av prostituerade eller homosexuell, men någon bestämd klarhet och bevis för det ena eller det andra saknas. En helt annan detalj i sammanhanget är att Nietzsches far dog i en ålder av trettiosex i vad man då kallade "hjärnuppmjukning", möjligen kan det också här ha handlat om neurosyfilis. Och därmed kan

68. Mann, Doktor Faustus, s. 206-207.

69. Ibid., s. 215, "Und, gütiger Himmel, war es nicht Liebe auch, oder was war es, welche Versessenheit, welcher Wille zum gottversuchenden Wagnis, welcher Trieb, die Strafe in die Sünde einzubeziehen, endlich: welches tief, geheimste Verlangen nach dämonischer Empfängnis, nach einer tödlich entfesselnden chymischen Veränderung seiner Natur wirkte dahin, dass der Gewarnte die Warnung verschmächte und auf dem Besitz dieses Fleisches bestand?”, Mann, Doktor Faustus I986, s. 206.

7o. Hayden, Pox, s. I89. 
det vara möjligt att Nietzsche, som var sjuklig redan som barn, hade medfödd syfilis och således smittats av sin mor. Men enligt Hayden förefaller denna teori osannolik, något hon inte närmare förklarar. Klart är dock att han led av sjukdomen och under långa perioder av sitt liv, även som yngre, besvärades av svåra magproblem, feber, svår huvudvärk, värk i ögonen och problem med synen. ${ }^{71}$

Det finns också en annan koppling mellan neurosyfilis och konst, nämligen konstnärer som vuxit upp med en far som led av sjukdomen. Johan Cullberg har i sin bok Diktarens kompost sett ett samband mellan Gunnar Ekelöfs mentala problem och alkoholism, och det faktum att han växte upp med en far som sakta föll samman mentalt och sedan dog i denna förfärliga sjukdom. En annan konstnär med en neurosyfilitisk far är den österrikiske Egon Schiele. Men den här sidan av sjukdomen kräver sin egen artikel, och jag går inte närmare in på det här.

Det finns en mängd spekulationer om olika kända personer som i slutskedet av sitt liv blev galna och således skulle ha kunnat lida av neurosyfilis. Men det är svårt att diagnostisera i efterhand då det inte finns dokumentation som med säkerhet skulle bevisa det ena eller det andra. Det påstås att Henrik VIII skulle ha lidit av syfilis och att sjukdomen kunde förklara hans irrationella beteende och det faktum att så få av hans barn överlevde. Men som jag nämnde tidigare bröt neurosyfilis ut först i samband med Napoleonkrigen långt senare. På I500-talet var också barndödligheten mycket stor av många andra orsaker.

Det är klart att neurosyfilis med alla sina myter och metaforer varit ett tacksamt ämne för många författare och konstnärer då sjukdomen var ett reellt hot i samtiden. I dag har den allmänna kunskapen om alla upptänkliga följder sjukdomen kunde ha, i det mesta gått förlorad. Det enda man kanske känner till är att man fick eksem och att det var en otäck sjukdom som kunde vara dödlig. Men det finns fortfarande

7I. Ibid., s. I93-I94. Alan Ryan,"The Will to Madness. The Story of Friedrich Nietzsche's Fateful Relationship with Richard and Cosima Wagner", The New York Times 24/ I I999, http://movies2.nytimes.com/books/99/or/24/reviews/99or24.24ryanlt.html (hämtad 20/2 20I9). 
ett intresse för att använda syfilis som en effekt inom populärkulturen. Syfilis förekommer i tv-serier som The Frankenstein Chronicles, The Alienist, i BBC-serien Victoria och i den tyska serien Babylon Berlin, för att nämna bara några exempel. Men sjukdomen används här som en effekt i bakgrunden och har ingen större betydelse i berättelsen $i$ stort. Personer i serierna har synliga eksem som indikerar syfilis, och därmed också promiskuitet, perversion eller alternativt återhållen sexualitet för att inte sprida smittan. Bara i ett fall, i Babylon Berlin, dör en person i sjukdomen. I tv-serien The Knick, som handlar om tidiga innovationer och behandlingar av sjukdomar på ett sjukhus $i$ New York kring I900, står syfilis i centrum. En kvinna får en näsa transplanterad och man botar hennes syfilis genom att smitta henne med malaria, något som också visade sig vara en effektiv behandlingsmetod på den tiden. Också författaren Anneli Jordahl skildrar i romanen Augustenbad en sommar (20II) en huvudperson som lider av syfilis och som spenderar en sommar på kuranstalt. Så syfilis kommer tillbaka, men i de här fallen i fiktiv form.

En viktig skillnad mellan de här moderna berättelserna om syfilis och berättelser skrivna före andra världskriget är att de i det första fallet behandlar syfilis som en tidsmarkör. Äldre berättelser har tagit ställning till sjukdomen både som ett samhällsproblem men också som en individuell katastrof. Guy de Maupassant drev med sig själv i yngre år och ironiserade över sin smitta när han fick veta om den, det var ett slags modesjukdom i hans kretsar under den tiden. Men inte desto mindre avslöjade han senare sin ångest i novellen "Horla". Hans biograf Robert Sherard ser sjukdom som en orsak till Maupassants produktivitet och genialitet, och lyfter därmed fokus från det promiskuösa och skambelagda till något fantastisk och beundransvärt. Detta fastän Maupassants liv slutade i en fasansfull ångest och misär.

Thomas Mann använder sjukdomen som en allegori för hela det tyska samhällets förfall i samband med nazismen och krigshandlingarna i Europa. Han undersöker genimyten genom sjukdomsberättelsen, men förhåller sig också skeptisk till den. Man kan kanske dra den slutsatsen att det inte är värt att bli ett geni, åtminstone inte till det priset. Ofrånkomligt väcks också frågan varför det alltid är män som förknippas med den här romantiska synen på geniet. Och varför biografer så aktivt intresserat sig för manliga konstnärers och författares 
könssjukdomar, som i det här fallet för syfilis. Det verkar fortfarande finnas ett samband mellan en beundran för en stor manlig konstnärs fantastiska produktion och intresset för hans sexuella virilitet. De kvinnliga biografiska berättelserna är färre och de två fall jag hittat av kvinnliga syfilitiker är också de kopplade till manlig virilitet; både Karen Blixen och Florence Foster Jenkins smittades tidigt i äktenskapet av sina respektive äkta män. Men inte desto mindre har syfilis varit en allvarlig och livsavgörande angelägenhet såväl för kvinnor som för män. 